\title{
道路交通騒音の予測モデルの適合性 COMPATIBILITY OF CALCULATION MODELS FOR ROAD TRAFFIC NOISE
}

\author{
金安 公 造* \\ By Kozo KANEYASU
}

\section{1. まえがき}

道路交通騒音の特徴は, 自動車といら移動する騒音源 が受音点に接近し，目前を通過し，遠ざかるに従って， 受音点の騒音が次第に大きくなり, 最大となり, また, 次第に小さくなるといら過程を示すことであり, 多数の 自動車が通過する場合には，それぞれの自動車からの騒 音が互いに影響し合い，また，個々の自動車の音響パワ 一は時間的にも変動し，この上うな過程が複雑に重なり 合って，不規則に変動する騒音となることである。

日本工業規格 ${ }^{1)}$ では, このように不規則にかつ大幅に 変動する騒音は中央値をもって騒音レベルを表示するこ ととしており，また，法令 ${ }^{2)}$ あるいは基準 ${ }^{3)}$ では，道路 交通騒音は原則として中央值で評価することとしてい る.したがって, 現在, 道路の計画, 設計等では, 道路 交通騒音の予測計算抢よび結果の評価は，一般に中央値 を対象としている.

一方, 道路交通騒音の評価指標としては, 英国 ${ }^{4)}$ では $L_{10}$ を採用して抢り，一方，オランダ5)，スウェーデ ン)，ドイッグ゙は $L_{e q}$ を基本とした評価指標が提案さ れている.このような国際的な動向を考慮すれば，わが 国においても今後は中央值以外の評価指標を検討する必 要があろう。

ある評価指標による評価量を設定する場合には，その 指標で表わされる騒音值を計算する手法を開発すること が必要である．中央値の予測計算については，一列等間 隔等パワーモデルから導かれた計算式が, 特定の条件の 場合に限定されているが広く実用に供されている ${ }^{8)}$. た, 道路交通騒音の変動状態を示す統計值 $L_{\alpha}$ あるいは エネルギー平均值 $L_{e q}$ を求めるモデルについても研究さ れている.しかし, これらのモデルは, 現時点では, わ が国においては広く実用に供されているとはいいがた

$*$ 正会員 建設省士木研究所道路部長
い.

実現象のモデル化のためには, 現象の抽象化が試みら れる. 道路交通騒音の予測モデルでは，現象を確定的に 取り扱う場合と不確定的に取り扱う場合とがある. 前者 の代表的なものとしては, 前述の等間隔等パワーモデル があり, 後者については, いくつかの研究がある ${ }^{9,10)}$.

モデルの構成の相違による計算值の差は, 音源である 自動車の個々の状態の影響を比較的大きく受ける音源に 近接した地点で明確に表われる. 一方, 音源から離れた 地点では, 音源の音響パワーおよびその配置の平均的な 状態によって, 受音点の騒音レベルはほぼ定まる。ま た, 音の伝搬過程に生ずる吸音, 反射, 回折などの現象 によって，実測値とこれらの現象を考慮していない計算 值との差の方が，モデルの構成の相違による計算値の差 よりも大きい場合が多い.

この報文では, 道路交通騒音の予測モデルの適合性を 検討するために，2.では，これまでに発表されている予 測モデルのおもなものを分類し, 確定的モデルとして等 間隔等パワーモデル，不確定的モデルとして指数分布モ デルおよび時間分布モデルの概要を述べる．次に，等間 隔モデルおよび指数分布モデルによる計算值の比較の結 果を紹介し，さらに道路交通騒音の予測計算における現 状の問題点について考察する. 3.では, 自動車が自由に 走行しているとみなすことができる 2 車線および 4 車線 道路の路有部における $L_{10}, L_{50}$ および $L_{90}$ の実測值と 等間隔モデル，指数分布モデルおよび時間分布モデルに よる計算値とを比較し，音源である自動車のパワーレベ ルの大きさおよびモデルの構成の相違について検討する ものである.さらに，4.では，道路から離れた地点につ いて $L_{10}, L_{50}$ および $L_{90}$ の実測值と過㮃減衰を考虑し た等間隔モデルおよび時間分布モデルによる計算值とを 比較して, これらのモデルの適合性を検討する. 最後に 5.では，これまでの結果をまとめるとともに，予測計算 方法についての今後の問題点を述べるものである. 


\section{2. 概 説}

\section{（1）道路交通騒音の予測モデル}

これまでに発表されている道路交通騒音の予測モデル は，以下のように分類できよう。

a) 経験的モデル ${ }^{11)}$

このモデルは，実際の道路で騒音レベルを実測し，同 時に, 交通条件 (交通量, 走行速度, 車種構成など), 道路条件（路面性状，横断形状など），伝搬条件（音源 からの距離, 地表面状況, 気象など) 等の中から, 騒音 レベルの大きさに関係すると考えられるいくつかの要因 を計測し，これらの要因と騒音レベルとの関係式を統計 処理によって求めるものである.

この方法は，現象のモデル化のためにはもっとも基礎 的な方法であり，測定条件の範囲内にある場合は，騒音 レベルを一定の精度で予測することができる。しかし， 考慮した要因と騷音レベルとの間の理論的な関係が明ら かにされていないため，測定条件外では適用できない. 各種の条件ごとに適用できるモデルを得るためには，そ れぞれの条件ごとに統計的に有意な実測資料を収集して 関係式を求める必要がある。

b) 解析モデル

このモデルは, 騒音レベルの大きさに関係する要因の 物理的特性をあらかじめ明らかにし，それらの要因と騒 音レベルとの関係式を解析的に求めるものである．音源 である自動車を連続袙音源と考えるモデルと，分離点音 源と考えるモデルが発表されている.

連続線音源モデルは, 交通量が非常に多くなって自動 車は一つの車線の中心線に沿って線状に均一に分布して いると考えるものであり，NCHRP Report 117²) では， 乗用車のみの 交通に 対するものとして式 (1) が示され ている.

$$
L_{50}=20+10 \log _{10} N-10 \log _{10} D+20 \log _{10} S
$$

ここで,

$L_{50}$ : 騒音レベルの中央值

$N$ : 自動車交通量（台/時）

$D:$ 車道中心線から受音点までの距離 $(\mathrm{ft})$

$S:$ 平均走行速度（マイル/時）

このモデルは音源として無限長の線音源を仮定してい るので, 騒音レベルは常に一定であり, したがって，中 央值以外の統計值 $L_{\alpha}$ を求めることはできない.

分離点音源モデルについて, 解析的に取り扱われてい るのは等間隔等パワーの場合であるが，これについては (2).a）で述べる. c）確率論モデル

解析モデルでは現象を確定的に取り扱っているのに対 して，確率論モデルは，音源である自動車の音響パワー の大きさ，あるいはその配置を不確定的に取り扱ってい る.

音響パワーに関しては，音源のパワーレベルがある一 定值に対して正規分布しているという考え方が，いわゆ るパワーにゆらぎがある場合として，また，自動車の配 置に関しては，車頭間隔が指数分布，あるいはアーラン 分布する場合などについてのモデルが研究されてい $る^{9), 10), 13)}$.

これらのうち, 指数分布モデルについては，(2). b) で述べる。

d）その他のモデル

解析モデルにせよ, 確率論モデルにせよ, 実際の現場 の複雑な条件を忠実にモデル化することは非常に困難で ある. 一般に, 地形, 道路等の条件は単純化してモデル 化しており，そのためにモデルの適用範用が限定されて いる.そこで, このような複雑な条件の場合にしばしば 用いられているのは, 三次元のスケールモデルを用いた 無響室内における模型実験である．この方法には，音響 特性および形状の相似，実験に用いる高周波音の補正な どについての制約があるが，特定の条件の現場における 予測方法としては有用な方法である.

また，条件の類似した現場あるいはスケールモデルに よって, 単一の走行車からの音の伝搬パターンを求め, 計画道路で想定される交通状況を電算機でシミュレート して, 騒音レベルを計算する, いわゆるハイブリッドモ デルがある ${ }^{9)}$.

\section{（2）検討したモデルの概要}

この報文では, 解析モデルとして等閒隔等パワーモデ ル, 確率論モデルとして指数分布モデルおよび時間分布 モデルを以下の検討の対象とする.

なお，この報文では特に定めるほかは，記号の定義は 以下のように定めた.

$P W L ： 1$ 台の車から発生する騒音のA特性による パワーレベル $(\mathrm{dB}(\mathrm{A}))$

$L_{W}: 1$ 台の車から発生する騒音のA 特性による 平均パワーレベル $(\mathrm{dB}(\mathrm{A}))$

$L:$ 受音点の騒音レベル $(\mathrm{dB}(\mathrm{A}))$

$L_{\alpha}$ : 時間の $\alpha \%$ を越える騒音レベル $(\mathrm{dB}(\mathrm{A}))$

$L_{50}$ : 時間の $50 \%$ を越える騒音レベル, すなわ ち騒音レベルの中央值 $(\mathrm{dB}(\mathrm{A}))$

$N$ : 自動車交通量（台/時）

$V:$ 平均走行速度 $(\mathrm{km} / \mathrm{hr})$

$l:$ 音源から受音点までの距離 $(\mathrm{m})$ 
表一1 一列等間隔等パワーモデルの前提条件

\begin{tabular}{|c|c|c|c|}
\hline$(1$ & 音 & 道 路 交 通 & (3) \\
\hline \multicolumn{2}{|r|}{$\begin{array}{l}\text { 自動車は無指向性 } \\
\text { 点源である。 }\end{array}$} & $\begin{array}{l}\text { (4) 息動車は一つの車 } \\
\text { 線の央を走行し } \\
\text { ている. }\end{array}$ & \multirow{2}{*}{ 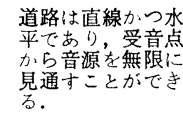 } \\
\hline \multirow[t]{2}{*}{ (2) } & \multirow{2}{*}{$\begin{array}{l}\text { それぞれの自動車 } \\
\text { は位相のでたらめ } \\
\text { な騷竟溌生して } \\
\text { 、て意波の涉な } \\
\text { とは無視できる. }\end{array}$} & \multirow{2}{*}{$\begin{array}{l}\text { (5) 走行している自動 } \\
\text { 車の頭間隔は扵 } \\
\text { テて等しい. }\end{array}$} & \\
\hline & & & 音源から受竟点ま \\
\hline & \multirow{2}{*}{$\begin{array}{l}\text { すへでの自動車の } \\
\text { 音響パワーは的し } \\
\text { ․ }\end{array}$} & \multirow{2}{*}{$\begin{array}{l}\text { 走行速度は等し } \\
\text { ๖. 加一定であ } \\
\text { る. }\end{array}$} & \\
\hline & & & $\begin{array}{l}\text { (9) 道路および沿道は } \\
\text { 音的に完射 } \\
\text { 体である. }\end{array}$ \\
\hline
\end{tabular}

$d:$ 平均車頭間隔 $(\mathrm{m})$

$a_{1}:$ 小型車類の混入割合

$a_{2}:$ 大型車類の混入割合

$a_{1}+a_{2}=1.00$

a）等間隔モデル（一列等パワーの場合）

このモデルは 1963 年に庄子ら ${ }^{14)}, 1968$ 年に Johnson and Sounders ${ }^{15)}$ によって発表されたものであり，モデ ルの前提条件は表一1に示すとおりである.

これらの条件から任意点の騒音レベルは式 (2) で求 まる.

$$
\begin{aligned}
L= & L_{W}+10 \log _{10} \\
& \cdot\left(\frac{1}{2 l d} \cdot \frac{\sinh 2 \pi \frac{l}{d}}{\cosh 2 \pi \frac{l}{d}-\cos 2 \pi \frac{v t}{d}}\right) \cdots \cdots(2)
\end{aligned}
$$

ここで,

$v:$ 平均走行速度 $(\mathrm{m} / \mathrm{sec})$

$t:$ 受音点の目前に車があった時からの時間 (sec)

また, 騒音レベルの統計值 $L_{\alpha}$ は式（3） で求まる. $L_{\alpha}=L_{W}+10 \log _{10}$

$$
\cdot\left(\frac{1}{2 l d} \cdot \frac{\sinh 2 \pi \frac{l}{d}}{\cosh 2 \pi \frac{l}{d}-\cos \pi \frac{\alpha}{100}}\right)
$$

式（3）において $\alpha=50$ とおくと， $L_{50}$ は式 (4) で 求まる.

$$
L_{50}=L_{W}+10 \log _{10}\left(\frac{1}{2 l d} \tanh 2 \pi \frac{l}{d}\right) \cdots \cdots(4)
$$

実際の現場は，表一1 にあげた条件に必ずしも適合し ない場合があるが，このような場合の補正については， 以下に述べるような考え方がある.

(1) 無指向性の点音源：この条件については (3).a) で検討する.

(2) 非干涉性 : この前提は各音源からの騷音レベルを 合成する場合にエネルギー和を求める，いわゆるパワー 合成するための条件であり，解析的な取り扱いを容易に している条件の一つである.

(3) 等パワー：走行している自動車は 1 台ごとに音響
パワーは異なり, また, 走行状態, 路面状態などによっ て時々刻々変化している. このような状態を常時等パワ 一とみなすことによって解析的な取り扱いは容易にでき るが，一方では実際との乘離を生ずる．そのための補正 としては, 次の二つの方法がある.

a. 車種を 2 または 3 種に大別し, 各車種は一定の音 響パワーを有しているとし, 各車種の混入割合を考慮し た平均パワーレベル $L_{W}$ を用いる確定的方法 ${ }^{8)}$

b. 自動車群全体について, 音響パワーは一定の平均 的な值からある変動幅をもって分布一一たとえば正規分 布 ${ }^{13)}$ しているとする不確定的方法

(4) 1 車線：式 (2) は 1 車線の場合について求めら れたものであり，2 車線以上については特定の交通状態 以外は, 解析的に式を求めることは困難である ${ }^{(4)}$. 中央 值の計算の場合は実用的な方法として，2 車線道路では 道路の中央に個々の自動車を点音源の列に配置して計算 しており，4 車または 6 車線などの道路では，上り・下 りの 2 方向のそれぞれの車道の中央にそれぞれの方向の 自動車の列を配置して方向別に求めた值を合成するとい う方法がとられている ${ }^{8)}$.

(5) 等間隔 : このモデルの特徴の一つであり, 解析的 な取り扱いを容易にしている条件の一つである.

(6) 等速度 : (5)条件が常時保たれるための条件であ る.

(7) 水平, 無限長の直線 : 音源が有限の場合は, 受音 点からの見通し角 $\theta$ を用いて, $\theta / \pi$ で音響エネルギーを 補正する方法が提案されている ${ }^{12)}$. 曲線道路では個々の 車を曲線上に配して, それぞれの車からの騷音レベルを 合成するという方法が考えられる. 道路に勾配がある場 合について, 中央值の変化と勾配との関係式を実測值か ら求めている例がある ${ }^{8)}$.

(8) 平坦性 : 伝搬経路に段差がある場合, 障壁あるい は盛土, 切土, 堀割, 高架道路などの肩で音が遮ぎられ る場合には, 音の回折減衰による補正が行われている ${ }^{8)}$.

(9) 完全反射 : 伝搬経路が地表面に近い場合には, 地 表面による音の吸収などによって, 距離による音の減衰 以外に, いわゆる過剰減衰を生じ, 一般に実測值は式 （2）による計算值よりも小さい. したがって，この前提 条件は計算值が大きめに計算される原因となっている.

b）指数分布モデル

このモデルは走行している自動車の車頭間隔は指数分 布していると考えるものであり, 一列等パワーの場合, 表一2 に示した条件と異なるのは(5)と(6)である.

高木ら ${ }^{13)}$ は音響パワーの等しい車が無限に長い1 車線 上を車頭間隔が平均 $d$ の指数分布をするような状態で走 行する場合, Fig. 1 のように 0 点から $i$ 番目の車まで の距離を $x_{i}$ とし, 車からの音は自由空間を球面波とし 


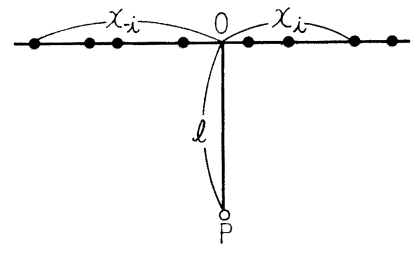

Fig. 1 一列指数分布・等パワー音源モデル

て伝搬するとして, 車線から $l$ 離れた地点 $P$ の音の強 さ $I_{W}$ を式 (5) で表わし，パワーレベルを $P W L$ とし た場合の受音点の音圧レベル $S P L$ を式 (6) で表わし ている.

$$
\begin{aligned}
& I_{W}=\sum_{i=-\infty}^{\infty} \frac{W}{4 \pi} \cdot \frac{1}{l^{2}+x_{i}{ }^{2}} \cdots \cdots \ldots \ldots \ldots \ldots \ldots \ldots . . . \cdots \cdots \cdots \\
& S P L=P W L+10 \log _{10} \sum_{i=-\infty}^{\infty} \frac{1}{4 \pi} \cdot \frac{1}{l^{2}+x_{i}{ }^{2}}
\end{aligned}
$$

次に,

$$
I=\sum_{i=-\infty}^{\infty} \frac{1}{4 \pi} \cdot \frac{1}{l^{2}+x_{i}{ }^{2}}
$$

とおいて, $I$ に対する特性関数を $g(u)=\exp [K(u)]$ と し, $I$ の確率密度関数 $P(I)$ を

$$
P(I)=\frac{1}{2 \pi} \int_{-\infty}^{\infty} e^{-i u I_{e} K(u)} d u
$$

で表わし， $K(u)$ を次の条件を満たす関数 $K_{1}(u)$ で近 似させた.

(1) $l \rightarrow 0$ および $l \rightarrow \infty$ では $K_{1}(u)=K(u)$

(2) $\exp \left[K_{1}(u)\right]$ のフーリエ変換 $P_{1}(I)$ を求めるこ とができ, かつ $P(I)$ が確率密度関数としての性質をそ なえている。

(3) $P_{1}(I)$ から定まる平均值 $\bar{I}_{1}$ が $K(u)$ から求まる $\bar{I}$ と一致し, 分散も $K(u)$ から求まる $\sigma_{I}{ }^{2}$ に近い值に なる。

このような $K_{1}(u)$ から $P(I)$ の近似式 $P_{1}(I)$ を求 め, 平均值 $\bar{I}_{1}$ および分散 $\sigma_{1}{ }^{2}$ を求めている.

また，音圧レベルの分布として，PWL=0 dBのとき の SPL の確率密度関数 $f(X)$ を $P_{1}(I)$ の式を用いて 表わし, 音圧レベルの平均 $\bar{X}$ および分散 $\sigma_{X}{ }^{2}$ をそれ ぞれ求めている.さらに，パワーレベルが，分布の標準 偏差が $\sigma(\mathrm{dB})$ で表わされる正規分布をしている場合に ついて, 音圧レベルの平均值 $\bar{X}(\overline{P W L}$ が $0 \mathrm{~dB}$ のと き）を求めており，これらの結果を電算機によるシミュ レーション計算の結果と比較してよく一致することを確 めている.

c）時間分布モデル

このモデルは 1973 年 Nelson ${ }^{16)}$ によって発表された ものであり，1台の自動車による受音点の騒音レベルの 時間率を求め，多数の自動車について合成することによ り，任意の交通量，車線数の道路からの騒音レベルの時

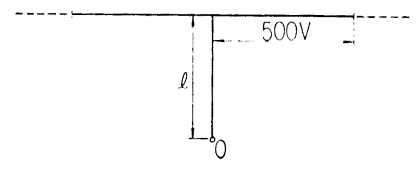

Fig. 2 一車線道路のモデル

間率を求めるものである.

Fig. 2 において 1 車線の 道路を 1 時間に 1 台の車が 走行しているとすると，この 1 台の車による受音点の最 大レベル $L_{\max }$ および最小レベル $L_{\min }$ は，それぞれ 式（8）および式（9）で求まる.

$$
\begin{aligned}
L_{\max }= & L_{R}+10 F \log _{10} R-10 F \log _{10} l \cdots \cdots(8) \\
L_{\min }= & L_{R}+10 F \log _{10} R-5 F \log _{10} \\
& \cdot\left\{(500 V)^{2}+l^{2}\right\} \ldots \ldots \ldots \ldots \ldots \ldots \cdots \cdots(9)
\end{aligned}
$$

ここで,

$L_{R}$ : 音源から $R(\mathrm{~m})$ 離れた地点の騒音レベル $(\mathrm{dB}(\mathrm{A}))$

$F$ : 音の減衰係数（半自由空間を伝搬するときは $F=2$ )

0 点における騒音レベルは $L_{\max }$ と $L_{\min }$ との間に あり，あるレベル $L$ を越えるレベルが観測される時間 率 $t(\%)$ は式（10）で表わされる.

$$
t=\frac{l(L)}{5 V}
$$

ここで,

$$
\begin{aligned}
& l(L)=\left[10^{\left\{\left(L_{R}-L\right) / 5 F+2 \log _{\mathrm{t} 0} R\right\}}+l^{2}\right]^{1 / 2} \\
& L_{\min } \leq L \leq L_{\max }
\end{aligned}
$$

任意の $L$ の值を式 (10) に代入することによって, その $L$ に対する $t$ の值が求まり，したがって，騒音レ ベルの時間率が求まる.このようにして求めた 1 車線上 を走行する単一車種による受音点の騒音レベルの時間率 を，交通条件拉よび道路条件に応じて車種ごと車線ごと に合成することによって, 任意の交通条件および車線数 の道路からの騒音レベルの時間率が求まり,この時間率 から任意の $L_{\alpha}$ および $L_{e q}$ を求めることができる.

\section{（3）予測計算における問題点}

a）音源のパワーレベル

予測計算のためには, 音源である自動車のパワーレベ ルの大きさを定める必要がある.一般には, ある速度で 走行している車から $l$ 離れた側方の地点の音圧レベル （SPL）を測定し，車を無指向性の点音源とみなし，車 からの音は半自由空間を伝搬するものとして式 (12) で 求めている.

$$
P W L=S P L+10 \log _{10} 2 \pi l^{2}
$$

一般に，自動車の音源はエンジン，ファン：ミッショ ン, タイヤと路面などであり，箃密な意味で無指向性の 点音源ではない，筆者ら ${ }^{17)} の$ 測定では，一般に側方で測 
定される音圧レベルは上方での值と比べると $3 \sim 5(\mathrm{~dB})$ 大きい，その理由としては，本は東体によって音源がカ バーされていることが考えられる．したがって，無指向 性の点音源とみなして式 (12) で求められるパワーレベ ルは，一般に大きめの值となっている．したがって，現 在, 一般に予測計算に用いられている音源のパワーレベ ルが適切なものであるかどうか検討することが必要であ る.

\section{b）予測モデルの構成}

高木ら ${ }^{13)}$ が指数分布モデルで求めた音圧レベルの平均 值を, シミュレーション計算の結果および等間隔等パワ ーモデルによる値と比較した結果によると, 音源のパワ ーレベルが等パワーの場合, lが小さい, すなわち, 道 路の近くでは, 等間隔モデルによるものが指数分布モデ ルによるものよりも2 3( $\mathrm{dB})$ 大きい值を示している. また， $/ d d$ がほぼ 2.5 を越えると両モデルによる音圧レ ベルの計算值にはほとんど差がない. $l / d=2.5$ は平均 走行速度 $60 \mathrm{~km} / \mathrm{hr}$ のとき, $l=50 \mathrm{~m}$ で 3000 台/時に相 当する. したがって，3000 台/時程度の交通量の道路か ら $50 \mathrm{~m}$ 以遠の地点では, モデルの違いによる計算値の 差はほとんどないといえる.

一方，パワーレベルが $\sigma=5(\mathrm{~dB})$ の正規分布をしてい る場合には, 等間隔モデルによる音圧レベルの平均值 は, 道路から $1000 \mathrm{~m}$ 程度離れた地点まで, 指数分布モ デルによる值よりも2 3( $\mathrm{dB})$ 小さい值となっている.

このことは, 現在, 実用上, 等間隔等パワーモデルによ って中央値を計算しているので, 予測計算上重要なこと であるが,この点については c) で検討する.

c）過剩減衰

一般に音源からの音は受音点に達する過程で吸収, 反 射, 回折などの影響を受ける. 回折については, 理論的 にも実験的にもほぼ明らかにされており，中央值の予測 計算の場合の補正の方法は明らかにされている ${ }^{8)}$. しか し, 吸収および反射については, 定量的な補正方法は明 確ではなく, 中央值の計算では, これらの影響は $\alpha_{i}$ と いら補正值に含めて処理されている ${ }^{8}$.

$\alpha_{i}$ の値は実測值からこれらの影響を考慮しない（回 折がある場合は回折を考虑した）計算值を減じた值から 定められたものであり, 高架道路の場合を除いて, 距離 による減衰以外の, いわゆる過剩減衰の大きさを示すも のである. 受音点が地表面に近いほど, また，音の伝搬 距離が長いほど， $\alpha_{i}$ の值は負の絶対值が大きい，才な わち, 計算值が過大となっている。たとえば，地上高 $1.2 \mathrm{~m}$ から $12.0 \mathrm{~m}$ までの, 道路から $80 \mathrm{~m}$ までの地点 では $-2.0(\mathrm{~dB}(\mathrm{~A}))$ 以下であり, 特に地上高 $1.2 \mathrm{~m} の$ $80 \mathrm{~m}$ 地点では $-10.0(\mathrm{~dB}(\mathrm{~A}))$ となっている ${ }^{18)}$.この ように実測值と計算值との差はモデル構成の違いによる
差一たとえば b) で紹介した等間隔等パワーモデルに よる計算值とパワーが正規分布している指数分布モデル による計算值との差 $(2 \sim 3(\mathrm{~dB}))$ 一よりも一般に大き い. すなわち, 地表面に近くかつ道路から離れた地点で は, モデルの構成の違いよりも過剩減衰の方が, 予測值 に与える影響が大きく，この影響をモデルの中にどのよ うに組み込むかが重要な問題である.

これらの問題点のうち，a）と b) は音源である自動 車の個々の状態を比較的大きく受ける音源に近接した地 点で明確に表われるので, 道路の路肩部での実測值と計 算值とを比較することによって検討する．また， c) に ついては, 当然のことであるが過剩減衰の影響が生ずる 道路から離れた地点（最大約 $80 \mathrm{~m}$ ) での実測值と計算 值とを比較することによって検討する.

\section{3. 路肩部における検討}

\section{(1) 実 測 值}

実測值としては 表一2に示すように，2 車線道路では 102，4 車線道路では 112 のデー夕を用いた．いずれの 道路もほぼ直線かつ水平であり, 近くに交差点, 踏切等 がなく, 自動車は比較的自由に走行している. 受音点の 地上高は $1.2 \mathrm{~m}$ であり, $L_{10}, L_{50}$ および $L_{90}$ は 10 分間 測定の騒音レベルの累積度数分布から求めた.

\section{（2）各モデルの計算条件}

a） 等間隔モデル

$L_{\alpha}$ は式（3）によって計算した. 平均パワーレベルは 日本音響学会 (以下, 日音会と記す) による式 (13) の 值帛を用いた。

$$
L_{W}=87+0.2 V+10 \log _{10}\left(a_{1}+10 a_{2}\right)
$$

b) 指数分布モデル

2. (2).b)で紹介した確率密度関数から音圧レベルの 平均值とその分散は求まるが， $L_{\alpha}$ はこのままでは求ま らない ${ }^{19)}$ ・したがって,ここではモンテカルロ法による

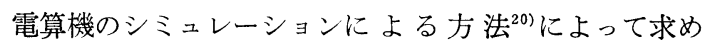
た. Fig. 3 に示すように, 図中の条件でおよそ 500 回

表一2 路肩部の実測值の交通条件

\begin{tabular}{|c|c|c|c|c|}
\hline 車線数 & 交通量の範国（台/時） & $\begin{array}{l}\text { デー } \\
\text { 夕数 }\end{array}$ & $\mid$\begin{tabular}{|} 
平均交通量 \\
(台/時)
\end{tabular} & $\begin{array}{c}\text { 平均走行速度 } \\
(\mathrm{km} / \mathrm{hr})\end{array}$ \\
\hline 2 車線 & $\begin{array}{c}156 \leqq N<500 \\
500 \leqq N<1000 \\
1000 \leqq N \leqq 1578 \\
\text { 部 }\end{array}$ & $\begin{array}{r}13 \\
56 \\
33 \\
102\end{array}$ & $\begin{array}{r}373 \\
805 \\
1210 \\
881\end{array}$ & 約 50 \\
\hline 4 車線 & $\begin{aligned} 600 \leqq & N<1000 \\
1000 \leqq & N \leqq 4446 \\
& \text { 計 }\end{aligned}$ & $\begin{array}{r}17 \\
95 \\
112\end{array}$ & $\begin{array}{r}865 \\
1943 \\
1780\end{array}$ & $60 \sim 70$ \\
\hline
\end{tabular}




\begin{tabular}{|c|c|c|c|c|c|c|}
\hline & \multirow{2}{*}{ 交通量の範团（台/時） } & \multirow{2}{*}{ デー夕数 } & 道 路 中 央 & \multicolumn{3}{|c|}{ 車線ごとに計算して合成する方法 } \\
\hline & & & 等 間 隔 $\left(E_{1}\right)$ & 等 間 隔 $\left(E_{2}\right)$ & 指数 分布 $\left(M_{2}\right)$ & 時間分布 $\left(T_{2}\right)$ \\
\hline \multirow{4}{*}{$L_{10}$} & $156 \leqq N<500$ & 13 & $+0.2(4.2)$ & $+2.0(4.4)$ & $+2.4(3.9)$ & $+1.7(4.3)$ \\
\hline & $500 \leqq N<1000$ & 56 & $+0.8(2.5)$ & $+0.6(2.4)$ & $+1.5(2.5)$ & $+0.9(2.4)$ \\
\hline & $1000 \leqq N \leqq 1578$ & 33 & $+0.8(2.3)$ & $-1.0(2.3)$ & $+0.2(2.5)$ & $-0.5(2.3)$ \\
\hline & Total & 102 & $+0.7(2.7)$ & $+0.2(2.8)$ & $+1.2(2.8)$ & $+0.6(2.8)$ \\
\hline \multirow{4}{*}{$L_{50}$} & $156 \leqq N<500$ & 13 & $-3.3(3.8)$ & $-0.4(3.8)$ & $-0.4(3.8)$ & $-0.5(3.8)$ \\
\hline & $500 \leqq N<1000$ & 56 & $-3.3(3.1)$ & $-0.6(3.1)$ & $-0.5(3.2)$ & $-0.9(3.1)$ \\
\hline & $1000 \leqq N \leqq 1578$ & 33 & $-2.9(2.1)$ & $-0.5(2.2)$ & $-0.2(2.0)$ & $-0.6(2.0)$ \\
\hline & Total & 102 & $-3.2(2.9)$ & $-0.6(2.9)$ & $-0.4(2.9)$ & $-0.8(2.9)$ \\
\hline \multirow{4}{*}{$L_{90}$} & $156 \leqq N<500$ & 13 & $-13.5(6.4)$ & $-10.5(6.4)$ & $-5.1(6.3)$ & $-5.6(6.5)$ \\
\hline & $500 \leqq N<1000$ & 56 & $-13.3(3.9)$ & $-10.5(3.9)$ & $-5.5(3.8)$ & $-5.8(3.9)$ \\
\hline & $1000 \leqq N \leqq 1578$ & 33 & $-13.6(3.6)$ & $-10.8(3.6)$ & $-5.8(3.7)$ & $-6.2(3.6)$ \\
\hline & Total & 102 & $-13.4(4.2)$ & $-10.6(4.2)$ & $-5.6(4.1)$ & $-5.9(4.2)$ \\
\hline \multirow{4}{*}{$L_{10}-L_{90}$} & $156 \leqq N<500$ & 13 & $+13.7(5.2)$ & $+12.5(5.3)$ & $+7.5(5.5)$ & $+7.3(5.2)$ \\
\hline & $500 \leqq N<1000$ & 56 & $+14.1(3.7)$ & $+11.0(3.9)$ & $+7.1(3.6)$ & $+6.7(3.8)$ \\
\hline & $1000 \leqq N \leqq 1578$ & 33 & $+14.4(3.8)$ & $+9.8(3.9)$ & $+6.0(4.0)$ & $+5.7(3.9)$ \\
\hline & Total & 102 & $+14.1(3.9)$ & $+10.8(4.1)$ & $+6.8(4.0)$ & $+6.5(4.0)$ \\
\hline
\end{tabular}

（）内は標染偏差 $s$ を示す。

(単位 : $\mathrm{dB}(\mathrm{A})$ )

(b) 4 車線道路

\begin{tabular}{|c|c|c|c|c|c|c|c|c|c|}
\hline & \multirow{2}{*}{ 交通量の範囲（台/時） } & \multicolumn{4}{|c|}{ 上り下りの 2 方向で計算して合成する方法 } & \multicolumn{4}{|c|}{ 各車線ごとに計算して合成する方法 } \\
\hline & & 多数 & 等 間 隔 $^{\left(E_{1}\right)}$ & $\begin{array}{c}\text { 指 数 分布 } \\
\left(M_{1}\right)\end{array}$ & $\begin{array}{c}\text { 時闑分布 } \\
\left(T_{1}\right)\end{array}$ & 齐数 & 等 ${ }_{\left(E_{2}\right)}^{\text {間 }}$ 隔 & $\begin{array}{c}\text { 指 数 分布 } \\
\left(M_{2}\right)\end{array}$ & $\begin{array}{c}\text { 時 間分布 } \\
\left(T_{2}\right)\end{array}$ \\
\hline \multirow{3}{*}{$L_{10}$} & $600 \leqq N<1000$ & 17 & $+0.3(2.5)$ & $+1.2(2.5)$ & $+0.9(2.5)$ & 17 & $+0.5(2.4)$ & $+1.4(2.5)$ & $+0.8(2.3)$ \\
\hline & $1000 \leqq N \leqq 4446$ & 95 & $+1.2(2.5)$ & $+1.5(2.4)$ & $+0.7(2.5)$ & 89 & $-0.1(2.4)$ & $+1.2(2.5)$ & $+0.6(2.5)$ \\
\hline & Total & 112 & $+1.0(2.5)$ & $+1.5(2.4)$ & $+0.7(2.5)$ & 106 & $-0.1(2.4)$ & $+1.3(2.5)$ & $+0.6(2.5)$ \\
\hline \multirow{3}{*}{$L_{50}$} & $600 \leqq N<1000$ & 17 & $-2.4(3.0)$ & $-1.7(3.0)$ & $-2.0(2.9)$ & 17 & $-0.1(2.8)$ & $-1.7(3.2)$ & $-2.1(2.9)$ \\
\hline & $1000 \leqq N \leqq 4446$ & 95 & $-2.6(2.4)$ & $-1.5(2.4)$ & $-1.9(2.4)$ & 89 & $-0.5(2.3)$ & $-1.5(2.5)$ & $-1.9(2.5)$ \\
\hline & Total & 112 & $-2.6(2.5)$ & $-1.6(2.5)$ & $-1.9(2.5)$ & 106 & $-0.5(2.4)$ & $-1.5(2.6)$ & $-1.9(2.5)$ \\
\hline \multirow{3}{*}{$L_{\varphi_{0}}$} & $600 \leqq N<1000$ & 17 & $-10.1(5.4)$ & $-5.2(5.4)$ & $-5.4(5.4)$ & 17 & $-7.6(4.9)$ & $-5.1(5.4)$ & $-5.5(5.3)$ \\
\hline & $1000 \leqq N \leqq 4446$ & 95 & $-10.3(3.7)$ & $-5.6(3.7)$ & $-5.8(3.7)$ & 89 & $-7.7(3.7)$ & $-5.6(3.7)$ & $-5.7(3.7)$ \\
\hline & Total & 112 & $-10.3(4.0)$ & $-5.5(3.9)$ & $-5.7(4.0)$ & 106 & $-7.7(3.8)$ & $-5.5(4.0)$ & $-5.7(4.0)$ \\
\hline \multirow{3}{*}{$L_{10}-L_{90}$} & $600 \leqq N<1000$ & 17 & $+10.4(3.7)$ & $+6.4(3.7)$ & $+6.3(3.8)$ & 17 & $+8.0(3.5)$ & $+6.5(3.7)$ & $+6.2(3.8)$ \\
\hline & $1000 \leqq N \leqq 4446$ & 95 & $+11.5(2.9)$ & $+7.1(2.7)$ & $+6.5(2.7)$ & 89 & $+7.5(2.8)$ & $+6.8(2.7)$ & $+6.3(2.7)$ \\
\hline & Total & 112 & $+11.3(3.1)$ & $+7.0(2.9)$ & $+6.4(2.9)$ & 106 & $+7.6(2.9)$ & $+6.7(2.8)$ & $+6.8(2.9)$ \\
\hline
\end{tabular}

（）内は標準偏差 $s$ を示す.

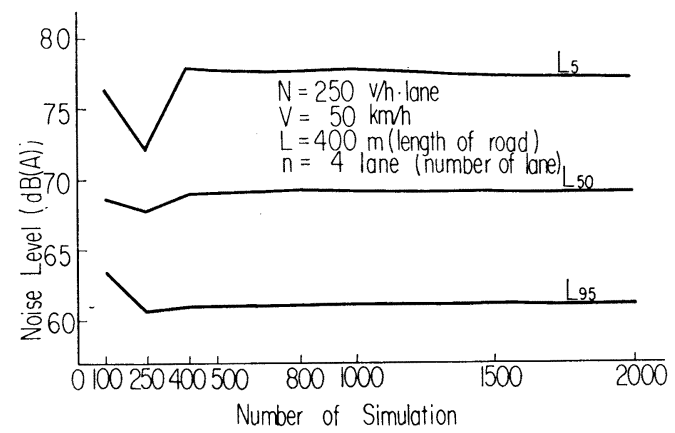

Fig. 3 騒音レベルとシミュレーションの回数

のシミュレーションで安定した值となったので, シミュ レーションの回数は 500 回とした.

パワーレベルは式 (13) のもととなった車種別のパワ ーレベルを用いた. 今回はパワーゆらぎのない場合, す なわち式（14）の值を用いた. $\left.\begin{array}{l}\text { 大型車類 } \\ \text { 小型車類 } \\ 87+0.2 \mathrm{~V}\end{array}\right\}(\mathrm{dB}(\mathrm{A}))$

c）時間分布モデル

式（11）において, $R=7.5 \mathrm{~m}, F=2.0$ として式 (10) から時間率 $t$ を求め, 交通条件, 車線ごとに合成して $L_{\alpha}$ を求めた. $L_{R}$ は $R=7.5 \mathrm{~m}$ として式 (15) に示す 值を用いた。

$\left.\begin{array}{l}\text { 大型車類 } L_{R}=71.5+0.2 \mathrm{~V} \\ \text { 小型車類 } L_{R}=61.5+0.2 \mathrm{~V}\end{array}\right\}(\mathrm{dB}(\mathrm{A})) \cdots$

\section{（3）実測值との比較}

a) 計算結果

実測值から計算值を減じた值 $\alpha$ の平均值 準偏差 $s$ は表一3のとおりである．等間隔モデルを $E$, 指数分布モデルを $M$, 時間分布モデルを $T$ で表わし， 2 車線道路の中央に全交通を配する方法および 4 車線道 路の上り下りの方向にそれぞれの方向の交通を配して求 
表-4 適合性の評価（路肩部，4 車線）

\begin{tabular}{|c|c|c|c|c|c|c|c|}
\hline & 交 通 量 (台/時) & $E_{1}$ & $M_{1}$ & $T_{1}$ & $E_{2}$ & $M_{2}$ & $T_{2}$ \\
\hline \multirow{3}{*}{$L_{10}$} & $600 \leqq N<1000$ & 0 & 0 & 0 & $\mathrm{O}$ & $\mathrm{O}$ & 0 \\
\hline & $1000 \leqq N \leqq 4446$ & 0 & 0 & 0 & $\mathrm{O}$ & 0 & 0 \\
\hline & Total & 0 & O & 0 & 0 & 0 & 0 \\
\hline \multirow{3}{*}{$L_{50}$} & $600 \leqq N<1000$ & $x$ & $x$ & $x$ & $x$ & $x$ & $\underline{x}$ \\
\hline & $1000 \leqq N \leqq 4446$ & $\times$ & 0 & $\mathrm{O}$ & 0 & $\mathrm{O}$ & 0 \\
\hline & Total & $x$ & 0 & $\mathrm{O}$ & 0 & $\underline{x}$ & $\bigcirc$ \\
\hline \multirow{3}{*}{$L_{90}$} & $600 \leqq N<1000$ & $x$ & $x$ & $\underline{x}$ & $\underline{x}$ & $\underline{x}$ & $x$ \\
\hline & $1000 \leqq N \leqq 4446$ & $x$ & $x$ & $x$ & $\underline{x}$ & $\underline{x}$ & $\underline{x}$ \\
\hline & Total & $x$ & $\underline{x}$ & $\underline{x}$ & $\underline{x}$ & $\underline{x}$ & $\underline{x}$ \\
\hline \multirow{3}{*}{$\begin{array}{c}L_{10} \\
1 \\
L_{90}\end{array}$} & $600 \leqq N<1000$ & $\bar{x}$ & $\bar{x}$ & $\bar{x}$ & $\bar{x}$ & $\bar{x}$ & $\bar{x}$ \\
\hline & $1000 \leqq N \leqq 4446$ & $\bar{x}$ & $\bar{x}$ & $\bar{x}$ & $\bar{x}$ & $\bar{x}$ & $\bar{x}$ \\
\hline & Total & $\bar{x}$ & $x$ & $\bar{x}$ & $\bar{x}$ & $\bar{x}$ & $\bar{x}$ \\
\hline
\end{tabular}

（注） $\bar{x}$ は計算值が実測值より小さい不可，正は大きい不可を示す。

めた值を合成する方法に 1 , また, 各車線別に求めた值 を合成する方法に 2 の添字を付して, それぞれの計算值 を示した.

\section{b) 考察}

計算値と実測值との適合性の評価を以下のように考元 て, 4 車線道路の結果を整理すると, 表一4 のように表 わされる.

$$
\begin{array}{ccccc}
\text { 評価 } & \text { 記号 } & \bar{\alpha} & s \\
\text { 良 } & \odot & |\bar{\alpha}| \leqq 1.5 & \text { かつ } & s \leqq 2.0 \\
\text { 可 } & \bigcirc & 1.5<|\bar{\alpha}| \leqq 2.5 & \text { かつ } & 2.0<s \leqq 2.5 \\
\text { 不可 } & \times & 2.5<|\bar{\alpha}| & \text { または } & 2.5<|s|
\end{array}
$$

（注）評価可の基準は，日音会の中央值の予測計算方 法において $\alpha_{i}=2.5, s=2.5$ であることを考虑 して定めた.

表一4の結果をまとめると以下のとおりである.

(1) $L_{10}$ については, 交通量 600 台/時 以上の場合は どの方法も適合性がある.

(2) $L_{50}$ については, 交通量 1000 台/時以上の場合は $E_{1}$ 以外の方法はほぼ適合性がある.

(3) $L_{90}$ および $L_{10}-L_{90}$ については，どの方法も適 合性はない.

c）計算所要時間
表一5 計算所要時間の一例

\begin{tabular}{l|r|r|r}
\hline & 等間 隔 & 指数分布 & 時間分布 \\
\hline 計 算 ケース & 106 & 108 & 112 \\
所 要 時 間 $(h)$ & 0.0043 & 1.1802 & 0.0416 \\
ーケース当りの所要時間 $(\mathbf{s e c})$ & 0.146 & 39.94 & 1.34 \\
等間隔を 1.00 としたときの比率 & 1.00 & 274 & 9.18 \\
\hline
\end{tabular}

表一5 は計算所要時間の一例である. 計算機は TOSBAK-5600-160 であり，用いるプログラム， 1 回の計 算で対象とするケースの数によって異なるが, 表に示し た例では, 1 ケース当りの所要時間の比率は, 等間隔モ デルを 1 とした場合，指数分布モデルはおよそ 275 , 時 間分布モデルはおよそ 9 であった。

\section{4. 道路から離れた地点での検討}

\section{（1） 実 測 值}

実測值としては, 表一6 に示したように, 2 車線道路 では 34，4 車線道路では 78 のデー夕を用いた. 受音点 の高さ抢よび $L_{\alpha}$ の求め方は路肩部の場合と同様であ り, $L_{e q}$ は式 $(16)^{9)}$ から計算した.

$$
L_{e q}=L_{50}+\frac{\left(L_{10}-L_{90}\right)^{2}}{56} \text {. }
$$

\section{（2）各モデルの計算条件}

路肩部での計算結果，指数分布モデルによる計算値と 時間分布モデルによる計算值とはあまり差がないが，電 算機による計算所要時間は後者は前者の約 $1 / 30$ である ので, 確率論モデルとしては時間分布モデルのみを検討 の対象とした.

a) 等間隔モデル

音の減衰係数を $F$ とすると, 平均パワーレベル $L_{W}$ の音源から $l$ 離れた地点の騒音レベルは,

\begin{tabular}{|c|c|c|c|c|c|c|c|c|c|c|}
\hline \multirow[t]{2}{*}{ 車線数 } & \multirow[t]{2}{*}{ 实 测 $゙$ デ } & \multicolumn{3}{|c|}{$\begin{array}{c}\text { 交通量 }(1000 \text { 台/時末満 }) \\
\left(\begin{array}{l}2 \text { 車線 } N=22 \\
4 \text { 車線 } N=15\end{array}\right)\end{array}$} & \multicolumn{3}{|c|}{$\begin{array}{c}\text { 交通量 }(1000 \text { 台/時以上) } \\
\left(\begin{array}{l}2 \text { 車線 } N=12 \\
4 \text { 車線 } N=63\end{array}\right)\end{array}$} & 合 & \multicolumn{2}{|c|}{$\left(\begin{array}{l}2 \text { 車線 } N=34 \\
4 \text { 車線 } N=78\end{array}\right)$} \\
\hline & & 最小 & 最大 & 均 & 最小 & 最大 & 均 & 最小 & 最大 & 平 \\
\hline \multirow{4}{*}{2 車線 } & 交 通 量（台/時） & 276 & 990 & 734 (219) & 1002 & 1578 & 1223 (186) & 276 & 1578 & $907(314)$ \\
\hline & 大型車混入率 (\%) & 6.3 & 36.9 & $21.3(8.9)$ & 18.0 & 29.2 & $22.4(2.9)$ & 6.3 & 36.9 & $21.7(7.3)$ \\
\hline & 平均事速 $(\mathrm{km} / \mathrm{hr})$ & 49 & 63 & $55.6(4.7)$ & 45 & 61 & $53.6(4.6)$ & 45 & 63 & $54.9(4.7)$ \\
\hline & 平均車頭間隔 (m) & 52 & 217 & $88.0(45.9)$ & 32 & 60 & $44.7(7.7)$ & 32 & 217 & $72.7(42.4)$ \\
\hline \multirow{4}{*}{4 車線 } & 交 通 量（台/時） & 744 & 972 & $900 \quad(73)$ & 1032 & 4446 & $1995(895)$ & 744 & 4446 & $1784(914)$ \\
\hline & 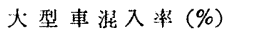 & 20.2 & 46.4 & $30.4(8.3)$ & 2.2 & 38.0 & $17.2(9.0)$ & 2.2 & 46.4 & $19.7(10.3)$ \\
\hline & 平均車速 $(\mathrm{km} / \mathrm{hr})$ & 50 & 62 & $59.6(3.4)$ & 52 & 68 & $59.0(4.1)$ & 50 & 68 & $59.1(4.0)$ \\
\hline & 平均車頭間嵒 (m) & 60 & 81 & $66.5(5.4)$ & 15 & 58 & $34.6(12.6)$ & 15 & 81 & $40.7(19.0)$ \\
\hline
\end{tabular}

$$
L=L_{W}-8-10 F \log _{10} l \cdots
$$

で表わされ, 式（3）は,

\section{表一6 実測值の交通条件}

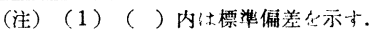

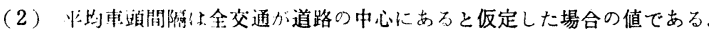



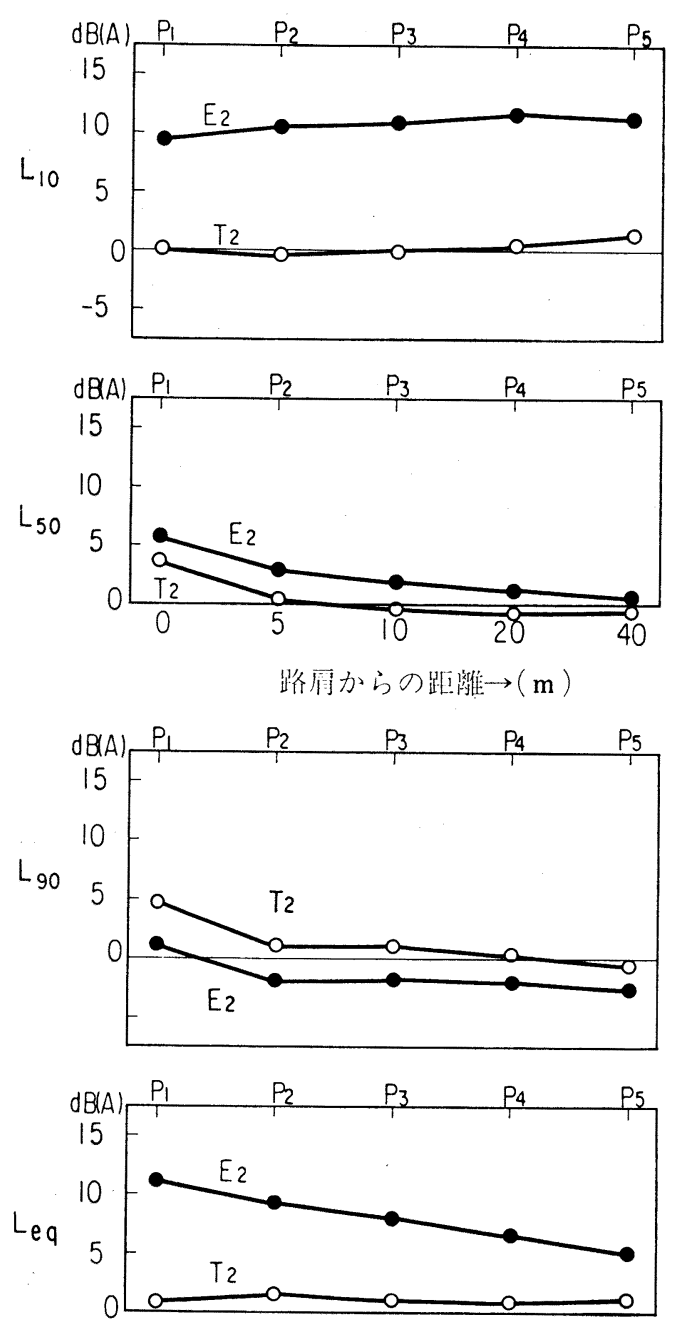

（a） 2 車線道路
表一7計算に用いた減衰保数

\begin{tabular}{l|c|c}
\hline 実測 值 の地表 面 の 状 況 & $F$ の值 \\
\hline 裸 & 2.4 \\
草地 $(10 \mathrm{~cm})$, 水间, 烟 (作物なL), 雑草地 $(20 \mathrm{~cm})$ & 2.8 \\
草地 $(30 \mathrm{~cm})$, 烟 $($ 作物あり) & 3.0 \\
\hline
\end{tabular}
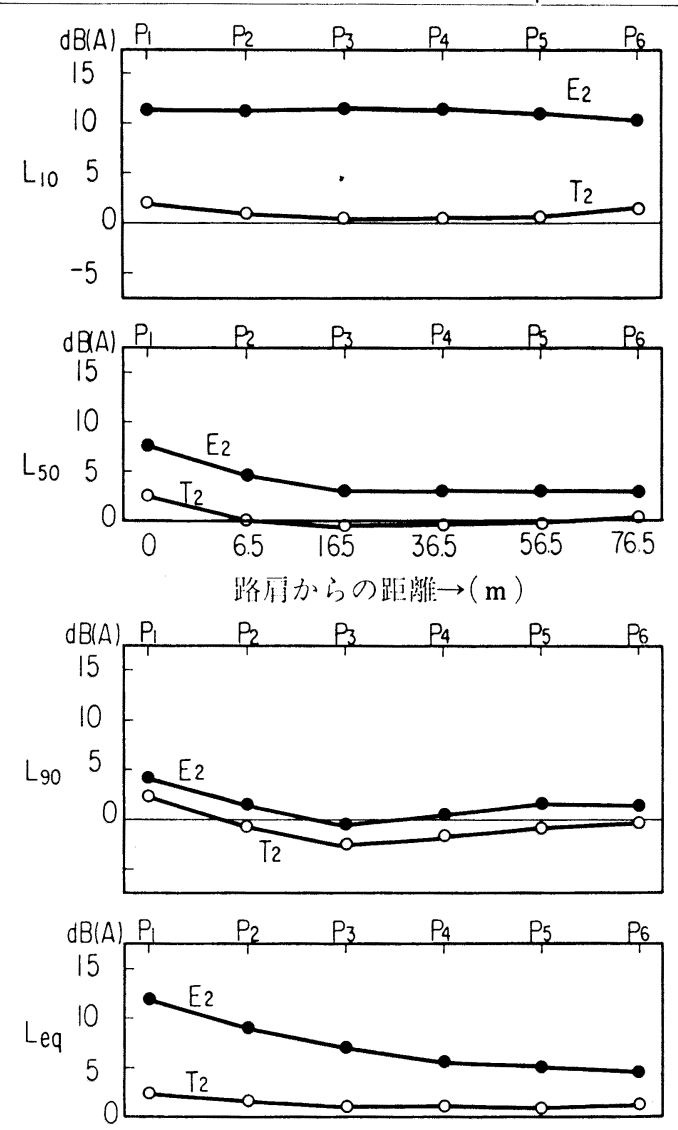

（b） 4 車線道路

Fig. 4 距離別の $\bar{\alpha}$ と $s$

$$
\begin{aligned}
L_{\alpha}= & L_{W}+5 F \log _{10} \\
& \cdot\left(\frac{1}{2 l d} \cdot \frac{\sinh 2 \pi \frac{l}{d}}{\cosh 2 \pi \frac{l}{d}-\cos \pi \frac{\alpha}{100}}\right)
\end{aligned}
$$

となる. $L_{10}, L_{50}, L_{90}$ は式 (18) から, $L_{e q}$ は式 (16) から求めた. 音源のパワーレベルは路肩部の計算と同じ く式（13）によった.

b）時間分布モデル

路肩部における計算と同じ方法によったが， $F$ の值は 実測地点の地表面条件に従って c) に述べるように定め た.

c) 減衰係数

減衰係数の実測資料として Nelson ${ }^{16)}$ および日音会 ${ }^{21)}$ の資料がある.これらの資料の $F$ の測定条件および騒
音レベルを実測した現場の条件を考慮して, 表一7 に示 す値を計算に用いた.

\section{（3）実測值との比較}

\section{a) 計算結果}

全データについて $\propto$ の平均值 $\bar{\alpha}$ と道路からの距離と の関係を示したのが Fig. 4 (a) および (b) である. また, 交通量 1000 台/時未満と 1000 台/時 以上およ び全データについて路有からの距離別の $\bar{\alpha}$ およ゙ $\alpha$ の 標準偏差 $s$ を表一8（a)，(b) に示した.

b) 考察

路肩部と同様に，4車線道路について適合性を評価す ると表一9のように表わされる．時間分布モデルを用い て車線ごとに計算して合成する方法 $\left(T_{2}\right)$ の適合性は以 下のとおりである。 


\begin{tabular}{|c|c|c|c|c|c|c|c|c|c|c|c|}
\hline & \multirow{2}{*}{$\begin{array}{l}\text { 交通量 } \\
\text { (台/時) }\end{array}$} & \multicolumn{2}{|c|}{$0 \mathrm{~m}$} & \multicolumn{2}{|c|}{$5 \mathrm{~m}$} & \multicolumn{2}{|c|}{$10 \mathrm{~m}$} & \multicolumn{2}{|c|}{$20 \mathrm{~m}$} & \multicolumn{2}{|c|}{$40 \mathrm{~m}$} \\
\hline & & $E_{2}$ & $T_{2}$ & $E_{2}$ & $T_{2}$ & $E_{2}$ & $T_{2}$ & $E_{2}$ & $T_{2}$ & $E_{2}$ & $T_{2}$ \\
\hline \multirow{3}{*}{$L_{10}$} & $N<1000$ & $8.8(2.8)$ & $0.9(2.8)$ & $10.1(3.4)$ & $1.7(2.5)$ & $10.9(3.6)$ & $1.4(2.7)$ & $11.8(3.2)$ & $1.2(2.0)$ & $11.2(3.0)$ & $1.6(2.3)$ \\
\hline & $1000 \leqq N$ & $10.5(1.8)$ & $-1.6(2.1)$ & $10.7(1.4)$ & $-2.1(1.3)$ & $11.3(1.7)$ & $-2.0(1.0)$ & $11.8(1.2)$ & $-1.5(1.8)$ & $11.4(0.6)$ & $0.8(0.1)$ \\
\hline & Total & $9.4(2.6)$ & $-0.0(2.8)$ & $10.4(2.6)$ & $-0.2(2.2)$ & $11.0(3.0)$ & $0.0(2.8)$ & $11.8(2.6)$ & 0.3 (2.3) & $11.3(2.8)$ & $1.5(2.2)$ \\
\hline \multirow{3}{*}{$L_{50}$} & $N<1000$ & $6.0(2.4)$ & $4.6(2.1)$ & $3.2(3.9)$ & $1.6(3.4)$ & $2.3(3.1)$ & 0.3 & $1.3(2.5)$ & $-0.5(2.4)$ & $0.6(2.4)$ & $0.6(2.0)$ \\
\hline & $1000 \leqq N$ & $4.8(1.8)$ & $2.2(1.7)$ & $2.4(1.8)$ & $-0.5(1.2)$ & $1.7(1.3)$ & $-1.3(0.8)$ & $1.7(1.1)$ & $-1.0(1.1)$ & $1.3(0.8)$ & $-0.9(0.7)$ \\
\hline & Total & $5.6(2.2)$ & $3.7(2.2)$ & $2.8(3.0)$ & $0.6(2.7)$ & $2.0(2.6)$ & $-0.3(2.4)$ & $1.4(2.1)$ & $-0.7(2.0)$ & $0.7(2.2)$ & $-0.7(1.8)$ \\
\hline \multirow{3}{*}{$L_{90}$} & $N<1000$ & $1.0(3.0)$ & $5.2(2.7)$ & $-3.3(4.4)$ & $0.7(3.9)$ & $-2.5(3.7)$ & $1.1(3.2)$ & $-2.5(3.9)$ & $0.5(3.4)$ & $-2.6(3.9)$ & $-0.5(3.4)$ \\
\hline & $1000 \leqq N$ & $1.2(2.2)$ & $4.1(2.0)$ & $-0.8(2.3)$ & $1.5(1.8)$ & $-0.8(1.9)$ & $0.9(1.4)$ & $-1.3(2.5)$ & $-0.6(1.8)$ & $-3.0(1.5)$ & $-3.2(1.2)$ \\
\hline & Total & $1.1(2.7)$ & $4.8(2.5)$ & $-2.0(3.6)$ & $1.1(3.0)$ & $-1.9(3.2)$ & $1.0(2.7)$ & $-2.1(3.5)$ & $0.1(3.0)$ & $-2.6(3.6)$ & $-0.8(3.3)$ \\
\hline \multirow{3}{*}{$L_{e q}$} & $N<1000$ & 11.7 (3.5) & $1.6(3.6)$ & $11.6(4.3)$ & $4.1(3.6)$ & $9.4(3.8)$ & $2.4(4.1)$ & $7.2(2.8)$ & $1.7(2.9)$ & $5.0(3.0)$ & $1.1(2.6)$ \\
\hline & $1000 \leqq N$ & $9.7(2.2)$ & $-0.3(1.9)$ & $6.9(1.1)$ & $-1.1(0.8)$ & $5.9(1.6)$ & $-1.4(0.9)$ & $5.4(1.5)$ & $-0.4(2.0)$ & $5.1(0.2)$ & $1.0(0.1)$ \\
\hline & Total & $11.0(3.2)$ & $0.9(2.8)$ & $9.3(3.9)$ & $1.5(3.7)$ & $8.1(3.5)$ & $1.0(3.7)$ & $6.6(2.6)$ & $0.9(2.8)$ & $5.0(2.8)$ & $1.1(2.4)$ \\
\hline
\end{tabular}

(注) $E_{2}$ : 等間隔等パワーモデル (車線こと合成), $T_{2}$ : 時間分布モデル (車線ごと合成)

(b) 4 車線道路

(単位: $\mathrm{dB}(\mathrm{A})$ )

\begin{tabular}{|c|c|c|c|c|c|c|c|c|c|c|c|c|c|c|c|c|}
\hline & \multirow{2}{*}{$\begin{array}{l}\text { 交通量 } \\
\text { (台/時) }\end{array}$} & \multicolumn{2}{|c|}{$0 \mathrm{~m}$} & \multicolumn{3}{|c|}{$6.5 \mathrm{~m}$} & \multicolumn{4}{|c|}{$16.5 \mathrm{~m}$} & \multicolumn{2}{|c|}{$36.5 \mathrm{~m}$} & \multicolumn{2}{|c|}{$56.5 \mathrm{~m}$} & \multicolumn{2}{|c|}{$76.5 \mathrm{~m}$} \\
\hline & & $E_{2}$ & $T_{2}$ & $E_{2}$ & & & & & & & $E_{2}$ & $T_{2}$ & $E_{2}$ & $T_{2}$ & $E_{2}$ & $T_{2}$ \\
\hline \multirow{3}{*}{$L_{10}$} & \multirow{3}{*}{$\begin{array}{c}N<1000 \\
1000 \leqq N \\
\text { Total }\end{array}$} & $10.1(4.4)$ & $2.4(2.0)$ & $10.3(4.7)$ & \multicolumn{2}{|c|}{$1.7(2.1)$} & \multicolumn{2}{|c|}{$9.2(4.2)$} & \multicolumn{2}{|c|}{$-0.4(1.7)$} & $11.1(4.4)$ & $0.6(2.2)$ & $10.5(4.1)$ & $0.4(4.2)$ & $10.2(4.3)$ & \multirow{3}{*}{$\begin{array}{l}0.6(4.1) \\
1.6(2.6) \\
1.4(3.0)\end{array}$} \\
\hline & & $12.1(3.2)$ & \multirow{2}{*}{$\begin{array}{l}2.0(2.2) \\
2.1(2.2)\end{array}$} & \multirow{2}{*}{$\begin{array}{l}11.6(2.8) \\
11.4(3.2)\end{array}$} & \multicolumn{2}{|c|}{$0.7(1.6)$} & \multicolumn{2}{|c|}{$12.1(2.8)$} & \multicolumn{2}{|c|}{$0.6(1.3)$} & $11.5(2.8)$ & $0.7(1.8)$ & $11.1(2.7)$ & $0.8(2.9)$ & $10.3(2.7)$ & \\
\hline & & $\mid 11.7(3.5)$ & & & & & 11. & 3.3) & & & $11.4(3.1)$ & $0.7(1.9)$ & $11.0(3.0)$ & $0.7(3.2)$ & $\mid 10.3(3.1)$ & \\
\hline & $N<1000$ & $7.7(4.9)$ & $2.5(3.1)$ & $5.3(3.7)$ & & & & 2.5) & -1 & 1.3) & $2.5(3.4)$ & $-0.9(2.7)$ & $2.2(4.2)$ & $-1.0(4.2)$ & $2.0(3.4)$ & $-1.2(3.4)$ \\
\hline$L_{50}$ & $1000 \leqq N$ & $7.6(3.4)$ & $2.6(2.6)$ & $4.3(2.4)$ & -0. & & & 1.9) & -0 . & 1.2) & $3.3(2.4)$ & $0.0(2.2)$ & $3.4(2.4)$ & $0.2(2.6)$ & $3.2(2.2)$ & $0.7(2.3)$ \\
\hline & Total & $7.7(3.7)$ & $2.6(2.7)$ & $4.5(2.7)$ & & $.7)$ & & 2.1) & -0 . & 1.3) & $3.1(2.6)$ & $-0.2(2.3)$ & $3.2(2.9)$ & $-0.1(3.1)$ & $2.9(2.6)$ & $0.2(2.7)$ \\
\hline & $N<1000$ & $3.3(7.7)$ & $2.4(6.0)$ & $1.0(6.0)$ & & & -2. & 4.9) & -3 & 2.6) & $-0.3(5.3)$ & $-1.4(3.6)$ & $-0.8(5.2)$ & $-2.1(4.3)$ & $-0.1(5.0)$ & $-1.4(4.0)$ \\
\hline \begin{tabular}{l|l}
$L_{90}$ & 1
\end{tabular} & $1000 \leqq N$ & $4.3(5.0)$ & $2.1(4.1)$ & $1.5(3.4)$ & -0.9 & & & $3.0)$ & & 2.2) & $0.6(3.2)$ & $-1.9(2.5)$ & 2.1(3.1) & $-0.5(2.5)$ & $1.7(3.8)$ & $-0.4(3.1)$ \\
\hline & Total & $4.1(3.9)$ & $2.1(4.5)$ & $1.4(4.0)$ & -0.7 & & -0 & 3.4) & -2 . & $2.2)$ & $0.5(3.7)$ & $|-1.8(2.7)|$ & $1.5(3.8)$ & $-0.8(3.0)$ & $1.3(4.2)$ & $-0.6(3.3)$ \\
\hline & $N<1000$ & $12.4(3.9)$ & $2.5(2.4)$ & $10.4(3.5)$ & & $.7)$ & & $3.0)$ & & 2.1) & $5.8(3.2)$ & $0.6(2.8)$ & $5.0(4.1)$ & $0.5(4.7)$ & $4.1(3.5)$ & $0.0(3.8)$ \\
\hline$L_{e q} 1$ & $1000 \leqq N$ & $11.6(3.1)$ & $2.4(2.1)$ & $8.6(3.0)$ & & & & 2.6) & & 1.9) & $5.7(2.5)$ & $1.1(2.2)$ & $5.1(2.5)$ & $1.0(2.9)$ & $4.7(2.3)$ & $1.6(2.5)$ \\
\hline & Total & $\mid 11.8(3.2)$ & $2.4(2.1)$ & $8.9(3.1)$ & & & & 2.6) & & 1.9) & $5.7(2.6)$ & $1.0(2.4)$ & $5.0(2.9)$ & $0.8(3.3)$ & $4.5(2.6)$ & $1.2(3.0)$ \\
\hline & & & & & & & & & & T) & 4 車線） & & & & & \\
\hline & 公诵昌 & （台/晆） & & & & & & & & & & & & $T_{2}$ & & \\
\hline & 人地五 & (1) & 0 & 6.5 & 16.5 & & 6.5 & 56 & & 76.5 & 0 & 6.5 & 16.5 & 36.5 & 56.5 & 76.5 \\
\hline & $N<1$ & 1000 & $\bar{x}$ & $\bar{x}$ & $\bar{x}$ & & $\bar{x}$ & $\bar{x}$ & & $\bar{x}$ & $\mathrm{O}$ & 0 & $\odot$ & 0 & $\bar{x}$ & $\bar{x}$ \\
\hline$L_{10}$ & 1000 & $\leqq N$ & $\bar{x}$ & $\bar{x}$ & $\vec{x}$ & & $\bar{x}$ & $\bar{x}$ & & $\bar{x}$ & 0 & $\odot$ & $\odot$ & $\odot$ & $\bar{x}$ & $\bar{x}$ \\
\hline & To & tal & $\bar{x}$ & $\bar{x}$ & $\bar{x}$ & & $\bar{x}$ & $\bar{x}$ & & $\bar{x}$ & 0 & $\bullet$ & $\odot$ & ○ & $\bar{x}$ & $\bar{x}$ \\
\hline & $N<$ & 1000 & $\bar{x}$ & $\bar{x}$ & 0 & & $\bar{x}$ & $\bar{x}$ & & $\bar{x}$ & $\bar{x}$ & $\odot$ & 0 & $\underline{x}$ & $x$ & $\underline{x}$ \\
\hline$L_{50}$ & 1000 & $\leqq N$ & $\bar{x}$ & $\bar{x}$ & $\bar{x}$ & & $\bar{x}$ & $\bar{x}$ & & $\bar{x}$ & $\bar{x}$ & $\odot$ & ○ & $\overline{0}$ & $\bar{x}$ & $\overline{0}$ \\
\hline & To & tal & $\bar{x}$ & $\vec{x}$ & $\bar{x}$ & & $\bar{x}$ & $\bar{x}$ & & $\bar{x}$ & $\bar{x}$ & ( ) & $\odot$ & 0 & $\underline{x}$ & $\bar{x}$ \\
\hline & $N<$ & 1000 & $\bar{x}$ & $\bar{x}$ & $\underline{x}$ & & $x$ & $\underline{x}$ & & $\underline{x}$ & $\bar{x}$ & $\bar{x}$ & $\underline{x}$ & $\underline{x}$ & $\underline{x}$ & $\underline{x}$ \\
\hline$L_{90}$ & 1000 & $\leqq N$ & $\bar{x}$ & $\bar{x}$ & $x$ & & $\bar{x}$ & $\bar{x}$ & $x$ & $\bar{x}$ & $\bar{x}$ & $\underline{x}$ & 0 & 0 & 0 & $\underline{x}$ \\
\hline & & tal & $\bar{x}$ & $\bar{x}$ & $\underline{x}$ & & $\bar{x}$ & $x$ & & $\bar{x}$ & $\bar{x}$ & $\underline{x}$ & $\underline{x}$ & $\underline{x}$ & $\underline{x}$ & $\underline{x}$ \\
\hline & $N<$ & 1000 & $\bar{x}$ & $\bar{x}$ & $\bar{x}$ & & $\bar{x}$ & $\bar{x}$ & $x$ & $\bar{x}$ & 0 & $\bar{x}$ & 0 & $\bar{x}$ & $\bar{x}$ & $\bar{x}$ \\
\hline$L_{e q}$ & 1000 & $\leqq N$ & $\bar{x}$ & $\bar{x}$ & $\bar{x}$ & & $\bar{x}$ & $\bar{x}$ & $\bar{x}$ & $\bar{x}$ & 0 & $\odot$ & ○ & 0 & $\bar{x}$ & 0 \\
\hline & To & otal & $\bar{x}$ & $\bar{x}$ & $\bar{x}$ & & $\bar{x}$ & $\bar{x}$ & $\bar{x}$ & $\bar{x}$ & 0 & 0 & 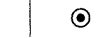 & 0 & $\bar{x}$ & $\bar{x}$ \\
\hline
\end{tabular}

(1) $L_{10}$ については，0〜36.5 m まで適合性がある.

(2) $L_{50}$ については，6.5〜36.5 m の区間はおおむね 適合性がある。

(3) $L_{90}$ については, 1000 台/時以上の場合, 16.5 $56.5 \mathrm{~m}$ の区間は適合性がある.

(4) $L_{e q}$ については，0 36.5 m まで，おおむね適合 性がある。

\section{5. 結論および今後の問題点}

(1) 結 論

これまでの検討結果をまとめれば，以下のとおりであ る 


\section{a) 路局部での検討}

(1) 現行の日音会のパワーレベルを用いた場合， $L_{10}$ については，どのモデルでも，実用上，日音会の予測計 算方法と同程度の適合性がある.

(2) 同様に $L_{50}$ については, 1000 台/時 以上の場合 は, どのモデルも適合性がある.

(3) $L_{90}$ および $L_{10}-L_{90}$ については，どのモデルで も前者は計算值が大きめに, 後者は小さめとなる. 特に 等間隔モデルでは, その傾向は著しい.

(4) 等間隔モデルは計算時間がもっとも早く, これを 1 とした場合, 指数分布モデルでは約 274 , 時間分布モ デルでは約 9 である.

b) 道路から離れた地点での検討

(5) 道路から離れた地点での予測計算は, 過剩减衰の 影響を考慮する必要があるが,一定の減衰係数を考慮し た時間分布モデルによると, 路肩からおよそ $40 \mathrm{~m}$ まで の $L_{10}, L_{50}$ および $L_{e q}$ の予測結果は, 日音会の方法と 同程度の適合性がある.

(6) 同様に $L_{90}$ については, 1000 台/時 以上の場合, 15 60 m の予測は適合性がある.

\section{(2) 今後の問題点}

（1）時間分布モデルを用いて, 道路近傍からおよそ $100 \mathrm{~m}$ までの予測を行う場合, 広い範囲にわたってよい 予測を得るためには, 距離によって值の異なる減衰係数 を用いる必要がある.

（2）今回は平坦開放な場合について検討したが，盛 土，切土，側方閉鎖などの場合についても適合性のある 予測計算方法を開発する必要がある.その方法として は，騒音レベルのユニットグラフを用いた時間分布モデ ルの応用が考えられる.

\section{謝辞：この研究は建設省土木研究所における調査} 研究の一環として行ったものであり,この報文の取りま とめに際してご協力を得た同所道路部交通環境研究室の 野中 宏研究員および (株) KCS 第二研究室長 金泉 昭氏ならびに小笠原氏に深く感謝する次第である。ま た，時間分布モデルについて直接の指導を賜った英国運 輸道路研究所環境部の P.M. Nelson 博士のご好意に厚 く御礼申し上げる.

\section{参考文献}

1) 日本工業標準調查会 : 騒音レベル測定方法, JIS Z 87311966, pp. 2，1969 年 8 月.

2）騒音規制法第 17 条第 1 項の規定に基うく指定地域内にお ける自動車騒音の限度を定める命令, 昭和 46 年 6 月 23 日, 総理府・厚生省令.

3）騒音に係る環境基準について, 昭和 46 年 5 月 25 日閣議 決定.

4) Building and Buildings : The Noise Insulation Regulation 1975.

5) Ministry of Public Health and Environmental Hygiene : Proposed Legislation on Noise Abatement in the Netherlands, Leidschenden, June, 1976.

6) Traffic Noise Committee : Summary in English, The Committee's Deliberations and Proposals, SOU 60, pp. 345 395, 1974.

7) Verein Deutscher Ingenieure : Beurteilung von Arbeitslärm in der Nachbauschaft, VDI 2058, Blatt 1, Juni, 1973.

8）日本音響学会 : 道路交通騒音の 予測計算方法に 関する研 究報告書, pp. 1 36, 1975.

9） 日本音響学会 : 道路交通騒音の予測における数学的モデ ルと評価量について, pp. 1〜77, 1975.

10）久野和宏・池谷和夫：ランダムに 分布した 点音源群から 放射された音響パワーの確率分布, 日本音響学会誌, Vol. 30, No. 5, pp. 268 275, 1974.

11）金安公造・金泉 昭: 道路交通騒音の予測式に関する一考察, 道路, pp. 28 35, 1974.

12) Highway Research Board: Highway Noise, A Design Guide for Highway Engineers, NCHRP Report 117, pp. 3 8, 1971.

13）高木興一・平松幸三・山本剛夫 : 指数分布モデルに 基づ 〈道路交通騒音の研究, 日本音響学会誌, Vol. 33, No. 6, pp. 325 332, 1977.

14）庄司 光 - 山本剛夫 - 中村隆一 : 街頭騒音とくに交通騒 音に関する研究, 日本音響学会誌, Vol. 19, No. 3, pp. 97 105, 1963.

15) D.R. Johnson and E.G. Saunders: The Evaluation of Noise from Free Felowing Road Traffic, J. Sound and Vib., 7(3), 1968.

16) P.M. Nelson : A computer Model for Determining the Temporal Distribution of Noise from Road Traffic, TRRL Laboratory Report 611, pp. 1 13, 1973.

17）金安公造・金泉 昭: 道路交通騒音と道路構造に関する 研究 (1), 土木研究所報告第 145 号, pp. 74 99, 1973.

18）石井聖光 : 道路交通騒音の 予測計算方法に 関する研究, 日本音響学会誌, Vol. 33, No. 8, pp. 426 430, 1977.

19）高木興一・藤木 修・山本剛夫：指数分布モデルにおけ る $L_{a}$ について, 土木学会第 32 回年次学術講演会講演概 要集第 4 部, pp. 336 337, 1977.

20) 庄司 光ほか: モンテカルロ法による 交通騒音の 推定, 土木学会論文集, No. 154 , pp. 34 39, 1968.

21）日本音響学会 : 道路交通騒音の 予測計算方法に 関する研 究（その 3 ) 報告書, pp. 18〜29, 1977.

(1976.2.23. 受付) 